\title{
The Evaluation of the Agro-Business Resource Potential in Southern Russia
}

\author{
Sklyarov Igor Yurievitch ${ }^{1}$, Sklyarova Yuliya Mikhailovna ${ }^{1}$, Latysheva Lyudmila Anatolevna ${ }^{1}$ \& Podkolzina \\ Irina Michailovna ${ }^{1}$ \\ ${ }^{1}$ Stavropol State Agrarian University, Stavropol, Russia \\ Correspondence: Sklyarov Igor Yurievitch, Stavropol State Agrarian University, 355017, Stavropol, 12 \\ Zootechnicheskiy Ln, Russia. E-mail: inf@stgau.ru
}

\author{
Received: October 15, 2014 Accepted: October 29, 2014 Online Published: December 30, 2014 \\ doi:10.5539/ass.v11n3p305 URL: http://dx.doi.org/10.5539/ass.v11n3p305
}

\begin{abstract}
The article presents the evaluation of the agro-business resource availability reveals the main factors which influence the agricultural industry and market. The author defined that the basis for the stable business activity development is the resource potential. Its effective use contributes to the increase of the effectiveness of branches and sub-complexes of agriculture in the region. The author proves the dependence of the resource potential of the material and technical facilities, human resources; the author defines the agricultural capacity in the agriculture of the region, reveals the dependence of the business activity development of the investment activity in the agrarian sector of the region's economy.
\end{abstract}

Keywords: resource potential, agro-capacity, resources, land, human resources, raw material, agriculture, agricultural industry, agricultural sector of economy, investment activity, business activity

\section{Introduction}

The basis for the stable development of the business activity in the agro-business is the resource potential. Its effective use contributes to the increase of the effectiveness of branches and sub-complexes of agriculture in the region (Thurlow, 2008). The resource potential in the context of this investigation includes material and technical facilities and human resourcing. Material resources in agro-business are represented by the main fixed capital assets, including land and stocks (Beierlein, 2013). Work forces of agro-business are characterised by the quantity and quality of the working-age population. Resource potential of the regional economy is assessed by the system of indices, which generally characterize the agro-capacity of the agriculture in the region. The peculiarities of the agro-business are conditioned by the necessity of completion of the market mechanism with the controlling influence of the state (Obst, 2007). The investments in the sphere of agriculture exercise a decisive influence on the agro-capacity parameters; its characteristic is the agro-business participation in the formation of the state's GDP.

The Social and economic characteristic of Stavropol Territory.

Stavropol territory is one of the main agricultural producers in the Southern Russia. It is specialized in corn and sunflower growing; the leading role in livestock breeding is occupied by the cattle breeding and fine-wooled sheep breeding. Gardening, vine growing, poultry breeding, swine breeding and bee breeding are also well developed.

Stavropol territory has 1152 commercial entities of different forms of ownership which interact with Russian Ministry of Agriculture and Ministry of Agriculture of the territory. Among them 453 agricultural organizations are involved in the agricultural production, there are 12.3 thousand of the peasant (farm) enterprises and 412 thousand of private subsidiary farmings. A lot of organisations of different business patterns appeared after the reforming of the agricultural sector of the Russian economy in 1990s. Now we can definitely say that the process of economic decentralization had a positive effect on the resource availability, since the resource economy and production effectiveness in agriculture increased under the growing influence of competitiveness (Stavropol Ministry of Agriculture, 2014).

M. Rizov (Rizov, 2002) noted in his report that the economic reforms in Eastern Europe and developing countries included both the privatization of the agricultural plant assets and restructuring of the state and 
co-operative farms. Restructuring of the agriculture led to the appearing of the several types of enterprises such as cooperatives, companies, farm enterprises and their combination (Hagan, 1978). A wide range of types of agricultural organisations can be found in most countries with transition economy. One of the countries having a variety of legal forms of agricultural organisations is Romania. Except the main types of agricultural organisations here one can find hybrid forms such as the combination of the individual farms and associations of big agricultural commodity producers (Gibson, 2001).

At the same time the analysis of the agricultural production of different agro-business organisation forms in Southern Russia shows that the wholesale agricultural industry makes the most effective use of the resources; it has the biggest ratio of all the produced agricultural production. The process of integration into agro-business is accompanied by the annual increase of the agricultural production output. The increase of the production output can be observed both in the sphere of plant growing and animal breeding. This process is observed in all the categories of enterprises.

The record harvests of the grain crops were gathered in Stavropol territory for the past two years. The ratio of the food grain is $83 \%$. This is one of the best results in the Russian Federation.

Despite the fact that the grain production is the main direction in agriculture and its share of the income is $74 \%$, significant volumes of the industrial crops are produced in the territory. The production of the milk and meat as well as marketable eggs and pond-fish in the territory has been stabilized. Poultry and swine breeding are on the upgrade. The increase of the production of the main types of the livestock products is provided due to the increase in productivity of the agricultural animals and poultry. Stavropol territory occupies the second place in Russia for the rate of output increase of marketable eggs. For the past five years the share of the economically feasible enterprises is maintained ion the level of $63 \%$ (37\% in Russia). (Sklyarov, 2013)

The agriculture is the leading branch in Stavropol territory, this fact is represented in Table 1.

Table 1. Indices of the agricultural character of the economy development in Russia and Stavropol territory, bln. roubles

\begin{tabular}{|c|c|c|c|c|c|c|c|c|}
\hline \multirow[t]{2}{*}{ Indicators } & \multirow[t]{2}{*}{2009} & \multirow[t]{2}{*}{2010} & \multirow[t]{2}{*}{2011} & \multirow[t]{2}{*}{2012} & \multirow[t]{2}{*}{2013} & \multirow{2}{*}{$\begin{array}{l}\text { 5-year } \\
\text { average }\end{array}$} & \multicolumn{2}{|c|}{$\begin{array}{c}2013 \% \\
\text { comparing to }\end{array}$} \\
\hline & & & & & & & 2009 & 2012 \\
\hline Gross Domestic Product of Russia & 41276.8 & 38807.2 & 45172.7 & 54585.6 & 56533.6 & 47275.2 & 137.0 & 103.6 \\
\hline including the agricultural products & 2461.4 & 2515.9 & 2618.5 & 3451.3 & 3529.9 & 2915.4 & 143.4 & 131.8 \\
\hline ratio of the agricultural production, $\%$ & 6.0 & 6.5 & 5.8 & 6.3 & 6.2 & 6.2 & 103.3 & 108.6 \\
\hline $\begin{array}{l}\text { Gross Regional Product of Stavropol } \\
\text { Territory }\end{array}$ & 275.0 & 277.3 & 316.9 & 382.5 & 403.5 & 331.0 & 146.7 & 120.7 \\
\hline including the agricultural products & 76.4 & 67.7 & 82.8 & 100.2 & 103.4 & 86.1 & 135.3 & 121.0 \\
\hline ratio of the agricultural production, $\%$ & 27.8 & 24.4 & 26.1 & 26.2 & 25.4 & 26.0 & 91.2 & 100.4 \\
\hline
\end{tabular}

During the investigated period GDP of Russia increased for 37\% while GRP of Stavropol Territory increased for $46 \%$. Production rate of agriculture generally in the country increased for $43.4 \%$, for the territory - for $35.3 \%$. Ratio of the agricultural production in Russia increased from 5.8 up to $6.2 \%$, and it decreased in territory from 27.8 to $25.4 \%$. Average ratio of the agricultural production for the investigated period in the territory is approximately $26 \%$ (compare with the values for Russia $-6.2 \%$ ).

In order to determine the development tendency of the agro-business as the most important component of the life-support system of people we investigate the agro-capacity of Stavropol territory which is the complex of indices that characterise the agrarian character and, consequently, the production safety of the Russian economy (Trukhachev, 2014).

\section{Methodology and Methods}

While conducting the investigation we initially selected the main factors which influence the agro-business development. These factors are shown in Figure 1.

Each factor includes certain resources which are characterised by the definite indices. Economic resources are the ratio of the agriculture production output in GDP; the share of investments aimed at supporting agriculture producers in the general amount of investments in the economy. Human resources are the share of people involved in the agrarian sector in the general amount of people working in the economy sector as well as other 
indices which characterise the potential of the workforce resources in the region. Land resources are the statistics of the land fund (tilled fields, agriculture lands, seeds etc.). Material and technical resources are the agricultural plant assets; stocks.

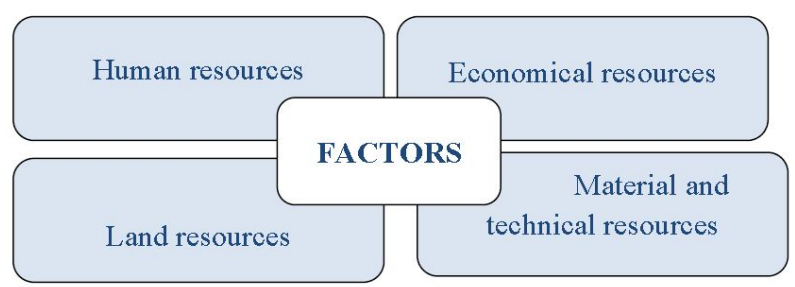

Figure 1. Factors that influence the agro-business development

In the course of the investigation we gathered the statistical information for each of the mentioned resource. The acquired data were processed with the help of the statistical economic analysis (comparison to the previous period, groupng and others).

\section{Result}

Estimation of agrocapacity of economy of region

In order to assess the agro-capacity of Stavropol territory comparing to Russia in Talbe 2 we arranged the structural parameters the most important of which are the ratio of the agriculture production output in GDP; share of people involved in the agrarian sector of economy in the general amount of people working in the economic sphere; share of investments aimed at supporting agricultural producers in the general amount of investments in the economy.

Table 2. Dynamics of the economy of agro-capacity parameters in Stavropol Territory, \%

\begin{tabular}{|c|c|c|c|c|c|c|c|c|}
\hline \multirow{2}{*}{ Indicators } & \multirow{2}{*}{2009} & \multirow{2}{*}{2010} & \multirow{2}{*}{2011} & \multirow{2}{*}{2012} & \multirow{2}{*}{2013} & \multirow{2}{*}{$\begin{array}{l}5 \text {-year } \\
\text { average }\end{array}$} & \multicolumn{2}{|c|}{$2013 \%$ comparing to } \\
\hline & & & & & & & 2009 & 2012 \\
\hline Share of the produced agriculture production in GDP & 27.8 & 24.4 & 26.1 & 26.2 & 25.4 & 26.0 & 91.2 & 96.8 \\
\hline $\begin{array}{l}\text { Share of food products turnover in the general amount of } \\
\text { retail turnover }\end{array}$ & 42.8 & 47.1 & 47.3 & 48.2 & 50.5 & 47.2 & 117.9 & 104.7 \\
\hline $\begin{array}{l}\text { Dependence of the agriculture production to the amount of } \\
\text { people's incomes }\end{array}$ & 23.4 & 18.2 & 19.2 & 20.9 & 18.8 & 20.1 & 80.3 & 90.0 \\
\hline $\begin{array}{l}\text { Share of people involved in the agrarian sector of } \\
\text { economy in the general amount of people working in the } \\
\text { economic sphere }\end{array}$ & 17.6 & 16.9 & 16.6 & 16.7 & 16.2 & 16.8 & 92.0 & 97.0 \\
\hline $\begin{array}{l}\text { Share of people involved in the agrarian sector of } \\
\text { economy in the general amount of people living in the } \\
\text { rural areas }\end{array}$ & 18.4 & 17.6 & 17.7 & 18.1 & 17.8 & 17.9 & 96.5 & 98.1 \\
\hline $\begin{array}{l}\text { Ratio of the rural population in the general amount of } \\
\text { people }\end{array}$ & 43.3 & 43.1 & 42.9 & 42.6 & 42.4 & 42.9 & 97.9 & 99.5 \\
\hline $\begin{array}{l}\text { Rate of remuneration in agricultural sphere comparing to } \\
\text { the average remuneration in the country }\end{array}$ & 74.9 & 74.9 & 78.0 & 81.7 & 83.3 & 78.6 & 111.1 & 101.9 \\
\hline $\begin{array}{l}\text { Share of investments aimed at supporting agriculture } \\
\text { producers in the general amount of investments in the } \\
\text { economy. }\end{array}$ & 15.4 & 13.3 & 11.6 & 12.4 & 10.5 & 12.6 & 68.2 & 84.7 \\
\hline Ratio of the farmlands area in the general land area & 87.5 & 87.5 & 87.5 & 87.5 & 87.5 & 87.5 & 100.0 & 100.0 \\
\hline Ratio of tilled fields area in the farmlands area & 69.4 & 69.4 & 69.4 & 69.4 & 69.4 & 69.4 & 100.0 & 100.0 \\
\hline Ratio of cultivated areas in the area of the tilled field & 73.3 & 74.0 & 71.9 & 71.1 & 70.4 & 72.1 & 96.0 & 99.0 \\
\hline $\begin{array}{l}\text { Crediting rate in the agriculture comparing to the average } \\
\text { crediting rate in the econommy }\end{array}$ & 148.2 & 147.7 & 145.2 & 142.7 & 141.2 & 145.0 & 95.3 & 98.9 \\
\hline
\end{tabular}

Share of people involved in the agro-business in the general amount of people working in the economic sphere has increased from 17.6 up to $16.2 \%$ in Stavropol territory. The ratio of the rural population in the general quantity of people decreased from 43.3 to $42 \%$. The conditions for agro-business activity remain generally on the same level; it is proved by the statistical data and calculations. The share of the farmlands in the general area of lands as well as the ratio of the tilled field in the farmlands has almost not changed $(87.5$ and $69.4 \%$ respectively). However the ratio of the cultivated areas in the tilled field area decreases from 73.3 to $70.4 \%$. Rate of remuneration in agricultural sphere decreased from 74.9 to $83.3 \%$ comparing to the average remuneration in the country. 
Comparison of the level of crediting rate in agro-business and average credit rates allowed drawing a conclusion about the inaccessibility of the credit resources which is conditioned by their expensiveness. As for the level of the state support, there appeared a favourable tendency to its increase (Simona, 2007). Share of investments aimed at supporting agriculture producers in the general amount of investments in the economy decreased from 15.4 to $10.5 \%$. This creates a serious problem for the process of updating of the main funds. Due to the growth of output agricultural organisations cannot provide the necessary amount of the agriculture equipment since they suffer the lack of financial resources. This is a global tendency. There is a global concern for the problem of financing of the agriculture. Investments into agriculture are one of the most effective methods of economic growth stimulation; they contribute to the stability of the production volume in agriculture of the regional economy (Lowder, 2011).

The tendencies of territory indices that overshoot the Russian ones show that the Stavropol territory economy is of more agricultural character comparing to that of the Russian Federation, which speak for the favourable conditions for the agro-business activity.

The statistical investigation allowed us to point out that the dynamics of the indices has low variability and, consequently, one can observe the stable character of the trends (Table 3) which is proved by the graphs of dynamics of the main agro-capacity characteristics and agro-support level (Figure 1).

Table 3. Evaluation of the agro-capacity parameters stableness in the Stavropol Territory economy, 2003-2013

\begin{tabular}{|c|c|c|c|c|c|}
\hline Indicators & $\begin{array}{l}\text { Average } \\
\text { value }\end{array}$ & Dispersion & $\begin{array}{l}\text { Average } \\
\text { standard } \\
\text { deviation }\end{array}$ & $\begin{array}{l}\text { Variation } \\
\text { coefficient }\end{array}$ & $\begin{array}{l}\text { Stableness } \\
\text { coefficient }\end{array}$ \\
\hline Share of the produced agriculture production in GDP & 7.4 & 2.1 & 1.5 & 0.2 & 0.8 \\
\hline $\begin{array}{l}\text { Share of food products turnover in the general } \\
\text { amount of trade turnover and food services }\end{array}$ & 7.9 & 10.9 & 3.4 & 0.4 & 0.6 \\
\hline $\begin{array}{l}\text { Dependence of the agriculture production to the } \\
\text { amount of people's incomes }\end{array}$ & 18.0 & 20.9 & 4.7 & 0.3 & 0.8 \\
\hline $\begin{array}{l}\text { Share of people involved in the agrarian sector of } \\
\text { economy in the general amount of people working in } \\
\text { the economic sphere }\end{array}$ & 10.5 & 1.8 & 1.4 & 0.1 & 0.9 \\
\hline $\begin{array}{l}\text { Share of people involved in the agrarian sector of } \\
\text { economy in the general amount of people living in } \\
\text { the rural areas }\end{array}$ & 18.6 & 1.6 & 1.3 & 0.1 & 1.0 \\
\hline $\begin{array}{l}\text { Share of the rural population in the general amount of } \\
\text { people }\end{array}$ & 26.8 & 3.0 & 1.8 & 0.1 & 1.0 \\
\hline $\begin{array}{l}\text { Rate of remuneration in agricultural sphere } \\
\text { comparing to the average remuneration in the country }\end{array}$ & 49.9 & 61.9 & 8.1 & 0.2 & 0.9 \\
\hline $\begin{array}{l}\text { Share of investments aimed at supporting agriculture } \\
\text { producers in the general amount of investments in the } \\
\text { economy. }\end{array}$ & 4.7 & 0.2 & 0.5 & 0.1 & 0.9 \\
\hline $\begin{array}{l}\text { Share of investments aimed at supporting agriculture } \\
\text { producers in the gross product of agriculture }\end{array}$ & 21.4 & 39.7 & 6.5 & 0.3 & 0.7 \\
\hline Ratio of the farmlands area in the general land area & 13.6 & 0.0 & 0.0 & 0.0 & 1.1 \\
\hline Ratio of tilled fields area in the farmlands area & 63.7 & 0.0 & 0.1 & 0.0 & 1.1 \\
\hline $\begin{array}{l}\text { Crediting rate in the agriculture comparing to the } \\
\text { average crediting rate in the economy }\end{array}$ & 144.1 & 315.1 & 18.4 & 0.1 & 0.9 \\
\hline
\end{tabular}

In order to increase the response of the resource potential in agro-business it is necessary to provide the balance of all the types of resources and their rational use in the process of production.

Let us consequently study the total of the resource potential of the region according to its types: land; workforce potential; main agricultural plant assets; stocks.

The analysis of presence and level of use of ground resources.

Lands of agricultural designation, the basis of which are the farmlands, occupy the territory designed for the the systematic use in agro-business. As for the 01.01.2013 the total area of the land fund in the territory has not changes, it is equal to 6616 thousand ga. (Table 4). The land fund of the territory is divided among 26 administrative districts and 10 cities of the territorial subordination.

Farmlands prevail in the territory; they occupy about $88 \%$ of the territory. This fact speaks for the high agricultural development of the land fund. The main type of the farmlands is a tilled field. Its ratio on the structure of farmlands is $69.1 \%$ (the ratio of the tilled field in the farmlands has increased for 0.04 for the report 
period). This fact speaks for the quite high degree of ploughing (Table 5). Stavropol territory has low level of tilled field use $-60 \%$. The main reason for this is the low business activity in the agriculture, lack of effective system of account and control for the farmlands use.

Table 4. Dynamics of the land resources changes, thousand ga

\begin{tabular}{ccccccc}
\hline Indicators & 2009 & 2010 & 2011 & 2012 & 2013 & Structure 2013, \% \\
\hline Total area of land, including & 6616 & 6616 & 6616 & 6616 & 6616 & - \\
farmlands, total & 5787.6 & 5787.3 & 5786.9 & 5786.9 & 5786.55 & 100.0 \\
among them:- tilled field & 3994.6 & 3995.7 & 3996.4 & 3997.7 & 3998.6 & 69.1 \\
- haylands & 105.2 & 105.2 & 105 & 105.1 & 105 & 1.8 \\
- pastures & 1628.8 & 1628.1 & 1627.8 & 1626.3 & 1625.8 & 28.1 \\
- forest & 113.2 & 113.2 & 113.3 & 113.2 & 113.25 & 2.0 \\
- ponds and water basins & 127 & 127 & 127 & 127 & 127 & 2.2 \\
- garden plots & 79.2 & 80.7 & 82 & 82.9 & 84.3 & 1.5 \\
- other lands & 125.8 & 125.5 & 125.4 & 125.4 & 125.2 & 4.6 \\
\hline
\end{tabular}

Table 5. Level of land fund use, $\%$

\begin{tabular}{cccccc}
\hline Indicators & 2009 & 2010 & 2011 & 2012 & 2013 \\
\hline Farmlands in the total land area & 87.48 & 87.48 & 87.47 & 87.47 & 87.47 \\
Tilled field in the farmland & 60.38 & 60.38 & 60.39 & 60.41 & 60.42 \\
Sowing in the tilled field area & 69.02 & 69.02 & 69.04 & 69.06 & 69.07 \\
\hline
\end{tabular}

The analysis of human resources.

Human resources in agro-business are of great importance since it uses a lot of hand labour. Human resources are the main working force for the performance of agricultural works; provide technical coordination, organisation and control of all the agricultural resources achieving optimum combination and use of means and tools of labour (Glaser, 2009). As for the agricultural production factors, one can say that the human resources significantly influence the business activity both in relation to the quantity and especially quality of the agricultural products. (Background document for the FAO, 2012). The main goal of the workforce management should be the use of the working time in the context of effectiveness, which results in the increase of the production rate indices. Rational use of the agricultural workforces can issue some questions concerning the degree of completeness and efficiency growth of the agriculture labour. Performance potential of the region is one of the most important indicators of the economic growth. Practical calculation of its main characteristics is a difficult task (Alexandratos, 1995).

The strong points of the performance potential are: prevailing of the share of the economically active population (64.7\%, the fourth place in the macro-regions of the Southern Federal District and North Caucasian Federal District, and 19th place in Russia); low general unemployment rate which, according to the calculation methods of International Labour Organization was $6.9 \%$ in 2013 (6.7\% in Russia, 9.8\% on the average in the regions of the Southern and North Caucasian Federal Districts, among them 5.1\% in Krasnodar territory, $34.1 \%$ in the Chechen Republic). As opposed to the most regions on Russia, the quantity of population is not the restrictive factor of the development in Stavropol Territory (Table 6).

The weak points are: low GRP values, low investments into the main capital and low fiscal capacity per one inhabitant of the territory; disproportion between the existing production volumes and population density (5 times more than the average population density in the RF); high degree of irregularity of economic and social development of the territory, depressive state of the eastern zone regions; growing inequality among people according to the income level; increase of the people who are in need of social support; professionals outflow and ageing, high mortality of the working age population, growing lack of the highly qualified professionals (The World Bank, 2012).

One can observe the increase of population in Stavopol territory. In 2000s the increase was insignificant and in 2013 the population of the territory has increased for 85 thousand people comparing to 2009 .

Economic activity level of the population in 2013 was $65.1 \%$ and increased for $0.2 \%$ in relation to 2009 . The highest increase of economic activity was observed in the urban area - it increased for 7.8 people. Urban population was $57.5 \%$ in the general amount of the economically active population. Occupational level has 
increases for $1.8 \%$ for the 2013 it was $61.6 \%$ which is higher than the similar index in the North Caucasian Federal district $(54.7 \%)$. At the same time this index is lower than that of the Russian Federation (64.3\%). Among the subjects of the North Caucasian Federal district the Stavropol territory occupies the 1st place for the occupational level.

Small business (farming, private subsidiary farmings) has positive effect on the employment of population, as well as individual labour, production of goods ad services for trading.

Table 6. The evaluation of the labour market and occupational level in the region

\begin{tabular}{ccccccc}
\hline Index & 2009 & 2010 & 2011 & 2012 & 2013 & $\begin{array}{c}2013 \% \text { comparing } \\
\text { to 2009 }\end{array}$ \\
\hline $\begin{array}{c}\text { Number of gainfully employed population, thousand } \\
\text { people }\end{array}$ & 1346.5 & 1363.6 & 1373.2 & 1383.4 & 1396.8 & 103.7 \\
Labour force participation rate, \% & 63.5 & 64.6 & 65.1 & 65.1 & 65.9 & 103.8 \\
Amount of employed people, thousand people & 1229.1 & 1270.0 & 1290.8 & 1309.2 & 1340.1 & 109.0 \\
Employment rate, \% & 57.9 & 59.4 & 61.2 & 61.6 & 63.3 & 109.2 \\
Number of unemployed, thousand people, including & 117.4 & 93.6 & 82.5 & 62.9 & 45.5 & 38.7 \\
men & 63.9 & 51.1 & 51.6 & 43.2 & 37.1 & 58.0 \\
women & 53.5 & 42.5 & 48.4 & 43.0 & 40.5 & 75.7 \\
Official unemployment rate, \% & 8.7 & 6.7 & 6.0 & 5.4 & 4.1 & 46.6 \\
\hline
\end{tabular}

Within the next three years the agro-business of Stavropol territory will have stable demand for the qualified labour and specialists. This occurs due to the implementation of investment projects and sectoral development strategies in Stavropol territory.

The analysis of the basic means.

Considering the indices of the main funds dynamics in Stavropol territory one can notice that the cost of the agricultural equipment in Stavropol territory has increased for 35.7\% for the period of $2009-2013$. But at the same time one can observe the decrease of almost all the indices of agricultural equipment presence in the agricultural organisations of the territory (Table 7).

Table 7. Material and technical facilities of the Stavropol Territory

\begin{tabular}{|c|c|c|c|c|c|c|}
\hline Indicators & 2009 & 2010 & 2011 & 2012 & 2013 & $\begin{array}{c}2013 \% \text { comparing } \\
\text { to } 2009 \\
\end{array}$ \\
\hline $\begin{array}{l}\text { Number of combines per } 1000 \text { ga of sowing } \\
\text { (bedding) of the corresponding plants }\end{array}$ & 3.0 & 3.0 & 3.0 & 3.0 & 3.2 & 106.7 \\
\hline $\begin{array}{l}\text { Number of tractors per } 1000 \text { ga of the tilled } \\
\text { field }\end{array}$ & 4.4 & 4.2 & 4.1 & 4.0 & 3.9 & 87.5 \\
\hline Equipment update coefficient & 1.8 & 2.2 & 4.3 & 2.6 & 3.9 & 213.9 \\
\hline Tilled field stocking per one tractor & 229.0 & 238.0 & 245.0 & 252.0 & 260.0 & 113.5 \\
\hline Park of the main types of equipment & 12527.0 & 13006.0 & 13485.0 & 13964.0 & 14443.0 & 115.3 \\
\hline Purchased new equipment & 231.0 & 266.0 & 495.0 & 293.0 & 425.0 & 184.0 \\
\hline $\begin{array}{l}\text { Sowing (bedding) of the corresponding } \\
\text { plants per one combine }\end{array}$ & 360.0 & 344.0 & 379.0 & 375.0 & 384.5 & 106.8 \\
\hline Generating capacity, h.p. & 5551.0 & 5382.0 & 5271.0 & 5291.0 & 5151.0 & 92.8 \\
\hline Generating capacity per one worker, h.p. & 69.0 & 67.0 & 66.0 & 67.0 & 65.5 & 94.9 \\
\hline $\begin{array}{l}\text { Generating capacity per } 100 \text { ga of the } \\
\text { cultivated area, h.p. }\end{array}$ & 268.0 & 271.0 & 242.0 & 244.0 & 231.0 & 86.2 \\
\hline
\end{tabular}

The analysis of the market of agricultural production, on a grain example.

During the past 5 years one can observe the growth of all types of agricultural production in Stavropol Territory. According to the results of 2013 the main traditional exporting branch of grain production had an increased export for $7.8 \%$ comparing to 2009 (Table 8 ). As the result the capacity of the domestic market, the structure of the grain resources in the territory and their use has changed. In 2009 the share of the production in the resource potential had only $73.1 \%$, and in 2013 it becomes $59.7 \%$. Closing stocks was significantly shortened from 17.7 to $10.9 \%$. The average export price in Russia is lower than the world one. 
Table 8 . The structure of the grain resources use, $\%$

\begin{tabular}{llllll}
\hline Index designation & 2009 & 2010 & 2011 & 2012 & 2013 \\
\hline Opening stocks & 17.7 & 16.4 & 14.5 & 12.5 & 10.9 \\
Production & 73.7 & 69.6 & 63.4 & 59.7 & 54.55 \\
Entry, including importing & 1.1 & 3.3 & 0.9 & 0.4 & 0.3 \\
Removal, including exporting & 79.2 & 80.1 & 83.5 & 88.2 & 90.35 \\
Closing stocks & 16.4 & 14.5 & 12.5 & 7.4 & 5.45 \\
\hline
\end{tabular}

Totally the agricultural production in all the categories of business for 2013 amounted to $121.1 \mathrm{bln}$ roubles in Stavropol Territory. Among them 73 bln roubles fall to the share of agricultural enterprises. The share of profit-making agricultural organisations amounted to $89 \%$, these organisations got the profit of 7.1 bln roubles. The profitability of all the business activity in the branch remained on the level of 2012 and amounted to $21 \%$. However the livestock breeding has the increase of this index for up to $7 \%$ in 2013.

Estimation of influence of innovations on agrarian sector of economy of region.

Introduction of power saving up effective technologies in agriculture of Stavropol Territory has not received a wide circulation as for this purpose it is required to update completely the production technology and will buy the new equipment and agricultural machinery. To make it for the agricultural commodity producers without attraction of additional financial resources in a category of credit or direct investments is impossible, this is the basic problem. As all large and small agricultural commodity producers which had possibility to obtain the credit - pay payments under the long-term credits received in previous year. They cannot receive a new credit for updating of the basic means in 2014. Therefore influence of innovations on economy of agrarian sector of Stavropol Territory the insignificant, and those grants (about 6 billion rbl. annually) allocated by the government on support of agriculture in edge allow to decide only current problems of landowners with circulating assets. Therefore without the state support a problem with introduction of innovative power saving up technologies in agriculture would not be solved.

\section{Conclusion}

As the result of the conducted investigation of the resource potential and agro-capacity of the Stavropol Territory we revealed the multiplying change and factors which influence the stableness and effectiveness of organisational-economic mechanisms development in agro-business. The investigation of the agro-capacity in the Stavropol Territory shows high potential of the agro-business development in the region. Generally, the economic potential of the agro-business activity in Stavropol Territory is defined by the following factors:

1. Positive:

- good production and financial indices comparing to other regions of the RF;

- high rates of economic growth (though with the account of their low rates at the beginning), they exceed the average Russian indices and, perhaps, will be kept on that level;

- increase of the quality of financial management and informational transparency of the agricultural organisations.

2. Negative:

- social and economic instability in the region. This is the retaining factor of investments growth in the agriculture;

- significant wear of the material and technical facilities of agro-business;

- low level of agriproduct processing;

- unstable financial results and variations of functional effectiveness of the agricultural organisations;

- exporting restrictions for the agricultural products of the territory;

- lack of investment resources;

- damping prices for the agricultural products imported to the territory.

Despite of the problems in the agrarian economy of the Stavropol Territory, positive tendencies such as increase of the agricultural production volumes prevail. One can also observe the implementation of intensive technologies, increase of investment activity, development of the business activity which all results in the appearing of the stable trend of production effectiveness increase in agro-business. However, there exist 
resources for the agro-business effectiveness increase. For this purpose with the assistance of the government institutions in the region it is necessary to create the conditions for the manufacturers which are aimed at stimulation of intensive energy-saving technologies implementation, to decrease the lack of production facilities for the storage and processing of the agricultural production; to provide the inflow of the qualified specialists to the agricultural organisations, make financial resources more affordable, increase the volume of the grant financial support for big, medium and small agricultural organisations, develop long-term programme of interventional policy implementation on the agrarian market.

\section{References}

Alexandratos, N. (1995). World agriculture: towards 2010: an FAO study. Chichester etc.: Food and agriculture organization of the United Nations.

Background document for the FAO. (2012). Agricultural production organization in transition economies and the role of human capital: evidence from Romania. Food and Agriculture Organization of the United Nations. Retrieved August 21, 2014, from http://www.fao.org/fileadmin/user_upload/tcsp/docs/2_Level\%20 trend $\% 20$ and $\% 20$ sources\%20of\%20financing\%20Final.pdf

Beierlein, J., Schneeberger, K., \& Osburn, D. (2013). Principles of Agribusiness Management (5th ed.). Long Grove, Illinois: Waveland Press.

Gibson, J. D. (2001). Agribusiness: management, marketing, human resource development, communication, and technology. Danville, Ill.: Interstate Publishers.

Glaser, L. S. (2009). Electrifying the rural American West: Stories of power, people, and place. Lincoln: University of Nebraska Press.

Hagan, J. P. (1978). Growth and adjustment in national agricultures: Four case studies and an overview. Montclair: Allanheld, Osmun.

Lowder, S. K., \& Carisma, B. (2011). Financial resource flows to agriculture: A review of data on government spending, official development assistance and foreign direct investment. ESA Working Paper. Rome.

Obst, W. J., \& Graham, R. (2007). Financial management for agribusiness. Collingwood, VIC: Landlinks Press.

Rizov, M. (2002). Agricultural production organization in transition economies and the role of human capital: Evidence from Romania. Retrieved from http://ecsocman.hse.ru/data/854/660/1219/018-157-rizov.pdf

Simona, C. C., \& Buzila, N. (2007). Analysis of the work productivity in the agricultural exploitations under the conditions of free market economy. Scientific progress on the Millennium. Publishing house Education and Science.

Sklyarov, I. Y., Bezdolny, T. Y., \& Nesterenko, A. V. (2013). Ways of formation and development of agricultural organizations in Russia and abroad, at the present stage of economic development. Bulletin AIC Stavropol, $6(2), 58$.

The official website of the Stavropol Ministry of Agriculture of the Russian Federation. The official website of the Stavropol Ministry of Agriculture of the Russian Federation. Retrieved August 18, 2014, from http://www.mshsk.ru/

The World Bank. (2012). Agricultural innovation systems an investment sourcebook. Washington, D.C. http://dx.doi.org/10.1596/978-0-8213-8684-2

Thurlow, J. (2008). Agricultural growth and investment options for poverty reduction in Zambia. Washington, D.C.: International Food Policy Research Institute.

Trukhachev, V. I., Mazloev, V. Z., Sklyarov, I. Y., \& Sklyarova, Y. M. (2014). Analysis of the market for agricultural products in South Russia. American-Eurasian Journal of Sustainable Agriculture, 8(6), 52-59.

\section{Copyrights}

Copyright for this article is retained by the author(s), with first publication rights granted to the journal.

This is an open-access article distributed under the terms and conditions of the Creative Commons Attribution license (http://creativecommons.org/licenses/by/3.0/). 